\title{
IDENTIFICATION AND LIFE CYCLE OF MARINE LEECH ISOLATED FROM CULTURED HYBRID GROUPER IN THE NORTHERN BALI WATERS OF INDONESIA
}

\author{
Ketut Mahardika\#, Indah Mastuti, Sudewi, and Zafran \\ Institute for Mariculture Research and Fisheries Extension \\ (Received 2 December 2017; Final revised 22 January 2018; Accepted 22 January 2018)
}

\begin{abstract}
The aims of this study were to identify and to determine life cycle of marine leech isolated from cultured hybrid grouper "cantik" (Epinephelus fuscoguttatus fx E. polyphekadion m in the northern Bali waters of Indonesia under laboratory conditions. Observation of the life cycle of the marine leech was done using petri-dishes $(9 \mathrm{~cm}$ in diameter) arranged into two groups. In group-1, a petri-dish was filled with sterile seawater (with water exchange of $50 \% 60 \%$ every two days) and in group-2, a petri-dish was filled with continuous running water. DNA sequence was aligned with the sequences from GenBank by BLAST program. Results of similarity index with GenBank sequence exhibited that the nucleic acid of the marine leech isolated from the hybrid grouper "cantik" showed high similarity $\left(99^{\circ} \%\right.$ with Zeylanicobdella arugamensis. One adult leech could produce 1-63 eggs. The eggs were developed into morula, blastula, and gastrula within five days. The early phase of the embryo with daily water exchange treatment started on day- 6 and hatched into larvae on day-10. The eggs incubated with continuous running water had hatched faster (eight days). However, not all eggs hatched at the same time. Some of the eggs hatched 1-3 days after the first one. Hatching rate of eggs varied from $2.70 \%$ to $100 \%$ The newly hatched $Z$. arugamensis larva has transparent color and length of 1.0-1.5 mm. On day-6, Z. arugamensis larvae were al ready seen attaching to the body of the fish. The size of the $Z$. arugamensis larvae ranged between 3-11 mm on day- 9 . In that stage, they were able to produce eggs. Therefore, we argue that $Z$. arugamensis only requires 17 to 22 days to develop into the adult stage.
\end{abstract}

\section{KEYWORDS: hybrid grouper "cantik"; life cycle; marine leech; Zeylanicobdella arugamensis}

\section{INTRODUCTION}

Leeches (Hirudinea) occur worldwide in a wide range of ecosystems including marine, estuarine, moist-terrestrial, and freshwater ecosystems (Moser et al., 2009). Among 680 known species, 15\%are marine water species and the rest are terrestrial and freshwater species. They are globally distributed on all continents except Antartica (Sket \& Trontelj, 2008). For example, a total of 13 parasitic leech species, consisting of three species from marine fish, eight species from freshwater fish, one species from brackish water fish, and one species from aquarium fish, have been found in different parts of Turkey (Arslan \& Oktener, 2012). One species (Pontobdella muricata, Linnaeus 1785) from a total of three species of ma-

\footnotetext{
\# Correspondence: Institute for Mariculture Research and Fisheries Extension. JI. Br. Gondol, Kec. Gerokgak Kab. Buleleng, Kotak Pos 140, Singaraja, Bali 81101, Indonesia.

Phone: + 6236292278

E-mail: kmahardika@ yahoo.com
}

rine leech was found on the dorsal surface of Thornback Ray, Raja clavata which was caught in 2013 in Antalaya, Turkey (Bulguroglu et al., 2015). Moreover, a total of 37 species belonging to six families and 19 genera are found in the North African countries (Ahmed et al., 2015a), including 13 leech species belong to two orders, two suborders, four families, and 11 genera found in Tunisia (Ahmed et al., 2015b). Recently, a new oioxenous marine leech species was isolated from external surfaces (mouth and cloaca) of the banded guitarfish Zapteryx exasperate caught in the Gulf of California and Eastern Pacific Ocean off the coast of San Diego, California. The leech was a scientific name as Austrobdella cairae n. sp. (Curran et al., 2016).

Leeches is divided into five major groups or orders including: the Rhynchobdellida (leeches with a proboscis), Gnathobdellida (jawed leeches), Pharyngobdellida (leeches that lack both a proboscis and jaws), Acanthobdellida (leech-like annelids that have retained chaetae/small bristles for locomotion), 
and the Branchiobdellida (Clark \& Panchen, 1971 in Govedich \& Bain, 2005). Moser et al. (2009) reported that generally, all leeches are sanguivorous (bloodfeeding). However, leeches exhibit a diverse range of feeding strategies where approximately half of the leech species predate on invertebrates and the others are blood-feeding ectoparasites. Gnathobdellida leeches create a hemorrhage with their jaws and teeth to consume the pooled blood or the body fluids of their host. Rhynchobdellida leeches protrude their proboscis into host tissue, which is followed by the release of salivary proteolytic enzymes at the tip of proboscis, and sucks the host's fluid. Rhynchobdellida encompasses two or three families namely Glossiphonidae, Piscicolidae, and Ozobranchidae. The Glossiphonidae are predacious and sanguiviorous freshwater leeches with a flattened, pear-shaped body and a poorly defined anterior sucker. The Piscicolidae are marine leeches having cylindrical bodies, and usually well-defined, bell-shaped anterior sucker. The Ozobranchidae can be found in the sea and freshwater environment and are not universally accepted as a distinct family of and often being merged with the Piscicolidae. Most Rhynchobdellids can swim by flattening their body and using dorsoventral undulations of the body. Leech species in the family of Piscicolidae that are often infested seawater fish are Pterobdella amara, Aestabdella leiostomi, and Zeylanicobdella arugamensis (Chandra, 1991).

Indonesian marine coastal region is one of the highest aquatic biodiversities on Earth (Yuniar et al., 2007; Palm, 2011). This includes fish species as well as their parasite fauna. For example, more than 25 different parasite species were found in orange-spotted grouper Epinephelus coioides cultured in Segara Anakan lagoon and Bali coastal areas from 2008 to 2009. They belonged to the following taxa: Ciliata, Microsporea, Digenea, Monogenea, Cestoda, Nemato da, Acanthocephala, Hirudinea, and Crustacea (Kleinertz \& Palm, 2013). The Hirudinea was reported affecting other groupers such as tiger grouper $E$. fuscoguttatus, marbled grouper E. polyphekadion, humpback grouper Cromileptes altivelis (Koesharyani et al., 2001), coral trout grouper Plectropomus leopardus and hybrid grouper. The affected fish showed sluggish movement and tended to swim on the surface of the water. The leeches attached on the fins (dorsal, caudal, and ventral), tail, gill operculum, mouth cavity, and ventral abdomen. The symptoms of leeches' infection are frayed fins, hemorrhages, and swelling of the host's skin (Cruz-Lacierda et al., 2000). The pathogenicity of this parasite was low, but a heavy infection might cause skin lesions leading to secondary bacterial infections (Koesharyani et al., 2001). The leech attached very strongly to the fish body. The adult leeches were migrated or detached from the fish body, and then lays of eggs on culture apparatus or containers. We have observed that leech infection in hybrid grouper cultured in floating net cages at Pegametan Bay, Northern Bali waters had caused injury to the fish body due to fish friction with the net. The fish became thin and weak with the body covered with leeches. The leech infestation in grouper occurs throughout the year, and until now the leech is still one of the main problems in grouper fish cultivated in floating net cages as well as grouper nursery in hatchery using direct sea water source.

Our experience demonstrated that treatments of fish using formalin and hydrogen peroxide done by fish farmers are only able to kill leeches attached to the fish, but a few weeks later the recovered fish is again filled with leeches. Therefore, it is necessary to know the life cycle and the ability of an adult leech to produce eggs. Such information could be used to develop a specific measure to cut or stop the leeches' life cycle.

The life cycle of leeches Zeylanicobdella arugamensis isolated from sea bass had been observed under laboratory condition which was set at $27^{\circ} \mathrm{C}$ using $28 \mathrm{ppt}$ sea water by Kua et al. (2010). The leech required 16 to 17 days to develop from a cocoon into mature stage. A study by Negoro (2017) showed that egg of $Z$. arugamensis maintained under laboratory condition at $24^{\circ} \mathrm{C}-25^{\circ} \mathrm{C}$ in seawater at $34 \mathrm{ppt}$ had developed from cocoon to mature on day-21. This present study also observed the life cycle of marine leech under laboratory conditions similar to the conditions undertaken by the two previous studies. However, in this study, two different seawater conditions for the rearing of the leeches were used and compared. The aim of this study was to identify and determine the life cycle of marine leech isolated from cultured hybrid grouper "cantik" (Epinephelus fuscoguttatus $f \times E$. polyphekadion $\mathrm{m}$ ) in the Northern Bali waters of Indonesia under laboratory conditions.

\section{MATERIALS AND METHODS}

\section{Source of Adult Marine Leech and Test Fish}

Adult marine leeches were isolated from hybrid grouper "cantik" (300-500 g). The hybrid grouper "cantik" with an average total length of 12-15 cm were used for growth observation of the marine leech. The fish were cultured at the Institute for Mariculture Research and Fisheries Extension, Gondol, Bali. 


\section{PCR and Sequence Analysis}

A total of 10-15 adult leeches were put into three microtubes. Genomic DNA was isolated using innuPREP DNA mini kit from Analytik Jena (Berlin, Germany) following the manufacturer's protocol. The mitochondrial cytochrome coxidase subunit I gene (COI) fragments were amplified using primers LCO 1490 and HCO 2198 from Tevsky \& Trontelj (2004) by applying 34 cycles of $45 \mathrm{~s}$ at $94^{\circ} \mathrm{C}, 45 \mathrm{~s}$ at $48^{\circ} \mathrm{C}$, and 1 min at $72^{\circ} \mathrm{C}$, after an initial three minute denaturation step at $94^{\circ} \mathrm{C}$. The PCR products were maintained at $4^{\circ} \mathrm{C}$ at the end of the cycling. The products were then separated by electrophoresis with $1.5 \%$ agarose gel in 1X TBE buffer (tris-borate-EDTA) containing 0.05 $\mu \mathrm{L} / \mathrm{mL}$ of red safe DNA stain.

Three samples of PCR products in a total volume of $50 \mu \mathrm{L}$ containing the amplified of $710 \mathrm{bp}$ fragment was purified using QIAquick PCR Purification Kit (Qiagen) according to the manufacturer's protocol. The purified DNA was sequenced using a DNA sequencer (Macrogen) using one oligonucleotide primer, LCO 1490 for sequence determination. The DNA sequences generated in this study were then aligned using Bioedit (Hall, 2011). DNA sequences were analyzed by BLAST program to know its similarity index.

\section{Observation of Egg Production and Hatching Rate}

Adult leeches were placed individually into rearing media using two different methods. In the first method, each adult leech was placed in a petri-dish (9 $\mathrm{cm}$ in diameter) containing $20 \mathrm{~mL}$ of sterile seawater (autoclaved at $121^{\circ} \mathrm{C}$ for 15 minutes) at 34 ppt salinity. In the second method, an adult leech was placed individually in a petri-dish $(9 \mathrm{~cm}$ in diameter) containing $30 \mathrm{~mL}$ of continuous running seawater at 3435 ppt salinity. In total, there were 27 petri-dishes were filled with sterile seawater and incubated in the wet laboratory at $29^{\circ} \mathrm{C}-31^{\circ} \mathrm{C}$. Culture water was exchanged $50 \% 60 \%$ with new sterile seawater every two days. In the second method, 30 petri-dishes filled with continuous running water were incubated in the wet laboratory at $29^{\circ} \mathrm{C}-31^{\circ} \mathrm{C}$. These methods were applied to observe the time of adult leech to produce eggs and the time of egg to hatch. The number of eggs produced on the petri-dish by each individual adult leech was observed every hour for 4-5 hours. The number of hatched eggs was observed daily for 15 days. The development of eggs was observed using a compound microscope (Leica DM 5000B) at two day intervals. Morphology of the embryo was recorded using a stereomicroscope camera and the size of eggs was measured using image analysis software. Hatching rate of the egg was also recorded.

\section{Experimental Infection of Leech Larvae to Healthy Juvenile Hybrid Grouper "Cantik"}

Healthy hybrid grouper "cantik" (TL: $12-15 \mathrm{~cm}$, $\mathrm{n}=6$ ) was treated with $100 \mathrm{mg} / \mathrm{L}$ formalin in fresh water for 30 minutes before used. Each three test fish were kept in $30 \mathrm{~L}$ fiber tank containing $25 \mathrm{~L}$ of sand-filtered seawater equipped with gentle aeration system. One petri-dish containing \pm 20 leech larvae was put in each fiber tank. The fish were fed with commercial diet twice a day. Water was exchanged $40 \% 50 \%$ with new sand-filtered seawater every two days. The development of leech from larvae to the adult stage and the ability to produce cocoons was observed every day for 15 days. The leech was then isolated from the test fish when its size was similar to those adult leech isolated from the infected hybrid grouper.

\section{RESULTS AND DISCUSSION}

The results of similarity index with GenBank sequence using BLAST program showed that the amino acid sequence of the marine leech isolated from hybrid grouper "cantik" had high similarity $(99 \%$ with Zeylanicobdella arugamensis as shown in Table 1. This result was indicated by the sequence of mitochondrial cytochrome c oxidase subunit I gene fragments obtained from the marine leech infecting the crimson snapper Lutjanus erythropterus in Penang, Malaysia (Ravi \& Yahaya, 2017). However, the sequence result of the marine Hirudinea based on a fragment of the gene coding for the small ribosomal subunit DNA (18S rDNA) had high similarity $(99 \%$ with four species of marine leech i.e: Z. arugamensis (DQ 414299.1), Pterobdella amara (DQ414289), Aestabdella leiostomi (DQ414252), and A. abditovesculata (DQ414254) (Negoro, 2017).

A random sampling of the adult $Z$. arugamensis with brown color $(n=83)$ had an average length of $7.56 \pm$ $2.27 \mathrm{~mm}(4-13 \mathrm{~mm})$ which was similar to the average length $(8.32 \pm 2.47 \mathrm{~mm})$ of adult $Z$. arugamensis with black color $(n=55)(4-13 \mathrm{~mm})$. The leech body is in small cylindrical shape. Two suckers were seen at the anterior end of the body with a diameter of $0.3-0.5$ $\mathrm{mm}$ and at the posterior end of the body which has a larger diameter of 1.0-1.8 mm. A pair of eyespots was located on the anterior sucker. The body has 12 segments, and its total length could extend twice from its initial body length. This leech moved quickly using two suckers. The leeches infecting hybrid grou- 
Table 1. Similarities of Zeylanicobdella arugamensis with the Hirudinea gene isolated from hybrid grouper "cantik"

\begin{tabular}{|c|c|c|c|c|c|}
\hline Description & $\begin{array}{c}\text { Maximal } \\
\text { score }\end{array}$ & $\begin{array}{l}\text { Total } \\
\text { score }\end{array}$ & $\begin{array}{l}\text { Query } \\
\text { cover }\end{array}$ & E value & Identification \\
\hline $\begin{array}{c}\text { Zeylanicobdella arugamensis isolate } \\
\text { KY441720.1 fish leech } 4 \text { cytochrome oxidase subunit } 1 \text { (COI) gene, } \\
\text { partial cds; mitochondrial }\end{array}$ & 1,094 & 1,094 & $90 \%$ & 0.0 & $99 \%$ \\
\hline $\begin{array}{c}\text { Zeylanicobdella arugamensis isolate } \\
\text { KY441719.1 fish leech } 3 \text { cytochrome oxidase subunit } 1 \text { (COI) gene, } \\
\text { partial cds; mitochondrial }\end{array}$ & 1,094 & 1,094 & $90 \%$ & 0.0 & $99 \%$ \\
\hline $\begin{array}{c}\text { Zeylanicobdella arugamensis isolate } \\
\text { KY441717.1 fish leech } 1 \text { cytochrome oxidase subunit } 1 \text { (COI) gene, } \\
\text { partial cds; mitochondrial }\end{array}$ & 1,088 & 1,088 & $90 \%$ & 0.0 & $99 \%$ \\
\hline $\begin{array}{c}\text { Zeylanicobdella arugamensis isolate } \\
\text { KY441721.1 fish leech } 5 \text { cytochrome oxidase subunit } 1 \text { (COI) gene, } \\
\text { partial cds; mitochondrial }\end{array}$ & 1,083 & 1,083 & $90 \%$ & 0.0 & $99 \%$ \\
\hline $\begin{array}{c}\text { Zeylanicobdella arugamensis isolate } \\
\text { KY441718.1 fish leech } 2 \text { cytochrome oxidase subunit } 1 \text { (COI) gene, } \\
\text { partial cds; mitochondrial }\end{array}$ & 1,083 & 1,083 & $90 \%$ & 0.0 & $99 \%$ \\
\hline
\end{tabular}

per "cantik" grew rapidly and were seen clustered with various sizes on the fish's body surface. Small leeches (1-2 $\mathrm{mm})$ were transparent or clear white, while larger size leeches (3-13 mm) had brownish and black color after they were deposited into petridishes.

The microscope observation of the skin scraps and gill pieces had found no eggs. Morphological findings in this study showed that the leech has similar characteristic to the $Z$. argumensis. The $Z$. argumensis have a pair of eyes on the anterior sucker. The body length ranged from 5 to $25 \mathrm{~mm}$ and the maximum body width at the middle of urosome was 0.6-2.3 $\mathrm{mm}$. The body could be divided into subcylindrical trachelosome and much longer and wider urosome. Anterior sucker was $0.3-0.5 \mathrm{~mm}$ in diameter and oval in shape. Posterior suckers were larger than oval sucker (1.6-1.8 mm in diameter). The body color was light brown and black color (Sawyer et al., 1982; Chandra, 1983; Ravi \& Yahaya, 2017).

Three out of $10(30 \%)$ adult $Z$. arugamensis that stocked in petri-dish were produced eggs after two hours, and $60 \% 90 \%$ of the $Z$. arugamensis were produced eggs one hour later (Table $2 a, b$ ). The leeches produced eggs at the same time in both of petridishes filled with seawater and continuous running seawater. The range number of eggs was $0-19$ in two hours and reached to $0-37$ in total three hours. The number of eggs produced by the adult $Z$. arugamensis in the petri-dish filled with seawater was higher than that of the adult $Z$. arugamensis in petri-dish filled with running seawater. We assumed that the number of eggs produced by the leeches when released from fish or deposited in petri-dish may depend on the condition of the leech or the fecundity of the leech. Some of the adult $Z$. arugamensis $(10 \% 40 \%$ did not produce eggs. It might be caused by the size of that Z. arugamensis which were less than $10 \mathrm{~mm}$ (6-8.5 $\mathrm{mm})$.

One adult leech could produce between 1-63 eggs for three days with hatching rate varied from $2.70 \%$ $100 \%$ (Table 3a, b). However, the eggs hatched at a different time which could last between 1-3 days. The developmental stages of eggs started from morula stage on day-1 of incubation (Figure 1A), then followed by blastula stage indicated by filamentous structure (Figure 1B). The gastrula stage was seen on the $3-5^{\text {th }}$ days (1C-D) indicated by the formation of the nerve cord. The early phase of embryo started on the $6^{\text {th }}$ day (1E) and was developed into an embryo (1F). During the embryonic development, the movement of the embryo was observed to be very active after $7-9^{\text {th }}$ days (Figure 1G). A total of 10 days were needed for new eggs to develop into larvae under $28^{\circ} \mathrm{C}-31^{\circ} \mathrm{C}$ at $34 \mathrm{ppt}$ with length ranged from 1-1.5 $\mathrm{mm}$. The eggs incubated with continuous running water under $29^{\circ} \mathrm{C}-31^{\circ} \mathrm{C}$ at $34-35 \mathrm{ppt}$ had hatched faster (eight days, Table $3 b$ ). 
Table 2a. The initial spawning period of the adult $Z$. arugamensis deposited in petri-dish filled with sterile seawater

\begin{tabular}{|c|c|c|c|c|c|c|}
\hline \multirow{2}{*}{$\begin{array}{c}\text { No. } \\
\text { petri-dish }\end{array}$} & \multirow{2}{*}{$\begin{array}{l}\text { Total adult } \\
\text { leech }\end{array}$} & \multicolumn{5}{|c|}{ Time observation the total number of eggs (hours } \\
\hline & & 1 & 2 & 3 & 4 & 5 \\
\hline 1 & 1 & 0 & 7 & 7 & 7 & 7 \\
\hline 2 & 1 & 0 & 0 & 0 & 0 & 0 \\
\hline 3 & 1 & 0 & 3 & 3 & 3 & 3 \\
\hline 4 & 1 & 0 & 0 & 2 & 3 & 3 \\
\hline 5 & 1 & 0 & 0 & 2 & 4 & 4 \\
\hline 6 & 1 & 0 & 0 & 0 & 0 & 0 \\
\hline 7 & 1 & 0 & 19 & 37 & 47 & 49 \\
\hline 8 & 1 & 0 & 0 & 0 & 0 & 0 \\
\hline 9 & 1 & 0 & 0 & 0 & 0 & 0 \\
\hline 10 & 1 & 0 & 0 & 3 & 4 & 4 \\
\hline \multicolumn{2}{|c|}{ Range } & 0 & $0-19$ & $0-37$ & $0-47$ & $0-49$ \\
\hline \multicolumn{2}{|c|}{$\begin{array}{l}\text { Percent of leech } \\
\text { product eggs (\%) }\end{array}$} & 0 & 30 & 60 & 60 & 60 \\
\hline
\end{tabular}

Table $2 b$. The initial spawning period of the adult $Z$. arugamensis from newly deposited in petri-dish filled with continuous running sea water

\begin{tabular}{|c|c|c|c|c|c|c|}
\hline \multirow{2}{*}{$\begin{array}{c}\text { No. } \\
\text { petri-dish }\end{array}$} & \multirow{2}{*}{$\begin{array}{l}\text { Total adult } \\
\text { leech }\end{array}$} & \multicolumn{5}{|c|}{ Time observation the total number of eggs (hours) } \\
\hline & & 1 & 2 & 3 & 4 & 5 \\
\hline 1 & 1 & 0 & 11 & 11 & 11 & 11 \\
\hline 2 & 1 & 0 & 0 & 2 & 13 & 13 \\
\hline 3 & 1 & 0 & 11 & 18 & 18 & 18 \\
\hline 4 & 1 & 0 & 3 & 3 & 3 & 3 \\
\hline 5 & 1 & 0 & 0 & 11 & 12 & 12 \\
\hline 6 & 1 & 0 & 0 & 7 & 7 & 7 \\
\hline 7 & 1 & 0 & 0 & 7 & 7 & 7 \\
\hline 8 & 1 & 0 & 0 & 4 & 8 & 8 \\
\hline 9 & 1 & 0 & 0 & 3 & 3 & 3 \\
\hline 10 & 1 & 0 & 0 & 0 & 0 & 0 \\
\hline \multicolumn{2}{|c|}{ Range } & 0 & $0-19$ & $0-37$ & $0-47$ & $0-49$ \\
\hline \multicolumn{2}{|c|}{$\begin{array}{l}\text { Percent of leech } \\
\text { product eggs (\%) }\end{array}$} & 0 & 30 & 90 & 90 & 90 \\
\hline
\end{tabular}

In the present study, the newly hatched $Z$. arugamensis larvae are transparent in color. Therefore, the larvae are difficult to see on the juvenile hybrid grouper "cantik". The juveniles $Z$. arugamensis already attached themselves to the body of the fish within six days, and they reached the size of 3-11 $\mathrm{mm}(\mathrm{n}=10)$ on day- 9 . In that stage, they were able to produce eggs (Figure 2 ). Thus, eggs from $Z$. arugamensis took 17-22 days to reach adult stage.
Fish parasites can be used as biological indicators for their host's health, accumulation indicators to detect pollutants, impact indicators to describe the relationship between pollution or eutrophication and the parasite, and as systemic indicators on the health status of the environment (Palm, 2011). Their occurrence or abundance can be used to describe the current status of the environment and even environmental change. Up to 25 different parasite species were 
Table 3a. The hatching rate of the adult $Z$. arugamensis from newly deposited eggs in petri-dish filled with sterile seawater

\begin{tabular}{|c|c|c|c|c|c|}
\hline \multirow{2}{*}{\multicolumn{2}{|c|}{ Petri-dish }} & \multirow{2}{*}{$\begin{array}{l}\text { Number } \\
\text { of eggs }\end{array}$} & \multicolumn{3}{|c|}{ Larvae observation } \\
\hline & & & 10 days & 11 days & Hatching rate $(\%)$ \\
\hline \multirow{7}{*}{ Plastic-dish } & 1 & 3 & 1 & 2 & 66.67 \\
\hline & 2 & 3 & 0 & 2 & 66.67 \\
\hline & 3 & 2 & 1 & 1 & 50 \\
\hline & 4 & 6 & 1 & 4 & 66.67 \\
\hline & 5 & 14 & 4 & 5 & 35.71 \\
\hline & 6 & 14 & 3 & 8 & 57.14 \\
\hline & 7 & 2 & 2 & 2 & 100 \\
\hline \multirow{10}{*}{ Glass-dish } & 8 & 8 & 8 & 8 & 100 \\
\hline & 9 & 15 & 15 & 15 & 100 \\
\hline & 10 & 3 & 3 & 3 & 100 \\
\hline & 11 & 3 & 3 & 3 & 100 \\
\hline & 12 & 7 & 5 & 5 & 71.43 \\
\hline & 13 & 15 & 15 & 15 & 100 \\
\hline & 14 & 18 & 18 & 18 & 100 \\
\hline & 15 & 16 & 16 & 16 & 100 \\
\hline & 16 & 12 & 10 & 10 & 83.33 \\
\hline & 17 & 13 & 13 & 13 & 100 \\
\hline \multicolumn{2}{|c|}{ Range } & $2-18$ & $0-18$ & $1-18$ & $35.71-100$ \\
\hline \multicolumn{2}{|c|}{ Average } & 9.06 & 6.94 & 7.65 & 82.21 \\
\hline
\end{tabular}

Table 3b. The hatching rate of the adult $Z$. arugamensis from newly deposited eggs in petri-dish filed with continuous running sea water.

\begin{tabular}{cccccc}
\hline \multirow{2}{*}{$\begin{array}{c}\text { No. of } \\
\text { petri-dish }\end{array}$} & \multirow{2}{*}{$\begin{array}{c}\text { Number } \\
\text { of eggs }\end{array}$} & \multicolumn{5}{c}{ Larvae } \\
\cline { 3 - 6 } & & 8 days & 9 days & 10 days & Hatching rate (\%) \\
\hline 1 & 9 & 5 & 6 & 6 & 66.67 \\
2 & 63 & 9 & 9 & 9 & 14.29 \\
3 & 6 & 2 & 4 & 4 & 66.67 \\
4 & 7 & 1 & 4 & 4 & 57.14 \\
5 & 2 & 0 & 1 & 1 & 50 \\
6 & 37 & 0 & 0 & 1 & 2.70 \\
7 & 7 & 1 & 4 & 5 & 71.43 \\
8 & 19 & 10 & 10 & 10 & 52.63 \\
9 & 5 & 0 & 1 & 1 & 20 \\
10 & 1 & 0 & 0 & 1 & 100 \\
11 & 19 & 7 & 10 & 10 & 52.63 \\
12 & 57 & 11 & 35 & 39 & 68.42 \\
13 & 22 & 6 & 9 & 11 & 50.00 \\
14 & 15 & 0 & 8 & 8 & 53.33 \\
15 & 17 & 2 & 6 & 6 & 35.29 \\
16 & 17 & 7 & 12 & 12 & 70.59 \\
17 & 10 & 3 & 7 & 7 & 70.00 \\
18 & 19 & 5 & 10 & 13 & 68.42 \\
19 & 6 & 0 & 4 & 5 & 83.33 \\
20 & 12 & 0 & 0 & 2 & 16.67 \\
\hline Range & $1-63$ & $0-11$ & $0-35$ & $1-39$ & $2.7-100$ \\
\hline Average & 17.5 & 3.45 & 7 & 7.75 & 53.51 \\
\hline
\end{tabular}




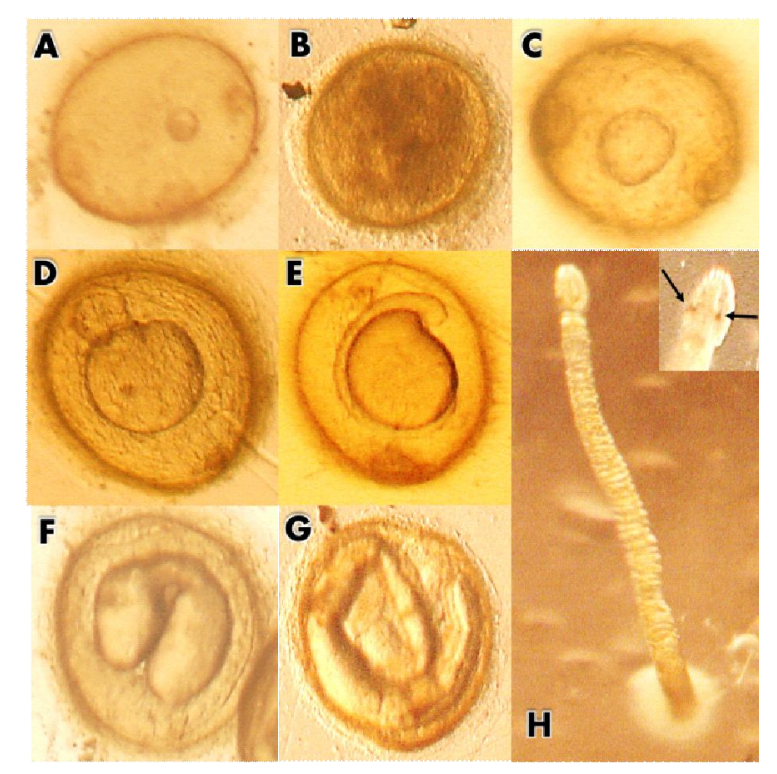

Figure 1. The developmental stages of eggs of $Z$. arugamensis in both of daily water exchange and running water under $28^{\circ} \mathrm{C}-31^{\circ} \mathrm{C}$ at 34 ppt. (A) morula stage; (B) blastula stage; (C) early gastrula; (D) late gastrula; (E); early embryo phase; $(F)$ development of embryo; $(\mathrm{G})$ active embryo; and $(\mathrm{H})$ newly hatched larvae (insert: the eye spots were seen on anterior sucker = arrows); Magnification 200X and 400X.

found in Epinephelus coioides from Java (Segara Anakan lagoon) and Bali waters (Kleinertz \& Palm, 2013). Kleinertz \& Palm (2013) also found that the parasite fauna of E. coioides in Segara Anakan lagoon had an increase in number and infestation from 2004 until $2008 / 2009$ which possibly related to an earlier oil spill events in 2002 and 2004. The fish from Segara Anakan demonstrated a significantly higher enzymatic activity (Hepatosomatic index) and a significantly reduced number of heteroxenous gut helminths (e.g. the digenean Didymodiclinus sp., the nematode Raphidascaris sp. and the acanthocephalan Serrasentis sagittifer) than those fish in Bali waters (Kleinertz et al., 2014). An abundant of parasitic species was reported infesting Epinephelus fuscoguttatus in a mariculture facility in the Thousand Islands, a marine national park. The occurrence of these parasites together with the prevalence of Trichodina spp., ecto-/ endoparasite ratio and endoparasite diversity illustrate a significant change in the culture conditions

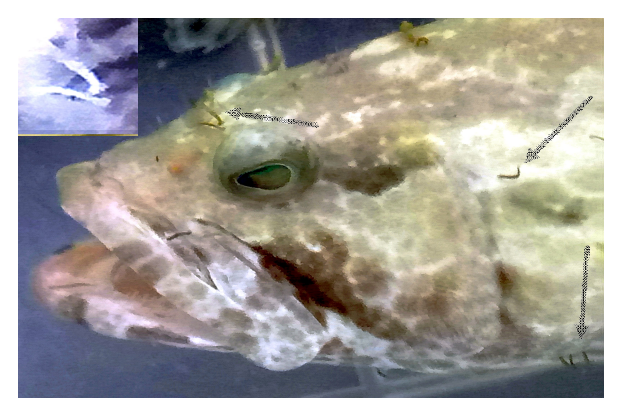

Figure 2. The leech-larvae development on juvenile hybrid grouper "cantik" in $25 \mathrm{~L}$ of seawater in $30 \mathrm{~L}$ fiber tank. Juveniles of $Z$. arugamensis attached to the fish in the head area (arrows), and two leeches attached to the head-skin (insert). 
over the years (Palm, 2011). The high biodiversity of metazoan parasites was also found in a total of 118 commercially important fish species from the southern Java coast. The trypanorhynch M ixonybelinia lepturi was the parasite with the highest intensity of infestation, and the zoonotic Anisakis sp. could cause a high-risk infestation on predatory fish (Jakob \& Palm, 2006). In addition, the ectoparasite fauna in the Karimunjawa Archipelago, Java Sea, was dominated by the monogenean Pseudorhabdosynochus quadratus resulting in a low Shannon index of species diversity of the entire parasite community $(0.17)$ (Neubert et al., 2016).

Leeches, at the species level, have not been used often for bio-assessment and monitoring of water quality. However, leeches have been shown to be useful as screening tools for biomonitoring certain organic chemical contaminants. For example, freshwater leeches from an industrially polluted creek were found to contain very high residues of chlorophenols (CPs) and DDT (Dichloro-Diphenyl-Trichloroethane) when compared with fish, tadpoles and other benthic invertebrates (Metcalfe et al., 1984; M oser et al., 2009).

Leeches are hermaphrodites with both male and female reproductive structures. M any undergo a brief protandrous stage at which the male tissues (testisacs) mature before the female tissue (ovisacs) (Moser et al., 2009). Kua et al. (2010) determined that the adult leeches have a total length ranging from 4.5 to $14.0 \mathrm{~mm}$. Moreover, they stated that the leeches with an average size of more than $10.0 \mathrm{~mm}$ were able to deposit eggs after 5-8 hours isolation, continuously until day-3. None of the leeches with an average size of $4.5-7.1 \mathrm{~mm}$ deposited eggs even though both ovary and testis were seen in each individual. The initial spawning experiment of the $Z$. arugamensis in this study was three hours more quickly than the initial spawning period of the adult $Z$. arugamensis from the study by Kua et al. (2010).

The development of eggs until hatching in this study was slower than the development of eggs of the $Z$. arugamensis isolated from sea bass reported by Kua et al. (2010). However, the development of the leech eggs lasted longer (11 days) when they were incubated under $24^{\circ} \mathrm{C}-25^{\circ} \mathrm{C}$ at $34 \mathrm{ppt}$ (Negoro, 2017). Kua et al. (2014) reported that the hatching rate of leech eggs was highest at a salinity of $30 \mathrm{ppt}$ (32.5 \pm $2.8 \%$ and decreased in lower salinity such as $20 \mathrm{ppt}$ $(18.0 \pm 4.3 \%)$ and 10 ppt $(12.1 \pm 1.4 \%$. They also found that the adult and juvenile leeches could live up to 4-7 days at salinity ranging from 10 to 40 ppt. The leech eggs were able to hatch at a temperature ranging from $25^{\circ} \mathrm{C}$ to $35^{\circ} \mathrm{C}$ but unable to hatch at $40^{\circ} \mathrm{C}$.

Many leeches are capable of breeding multiple times (iteroparous) and exhibit saltatory (irregular) growth after reaching reproductive maturity. The typical life cycle of leeches consists of egg (which is deposited inside a cocoon), juvenile, and reproductive hermaphrodite adult (Moser et al., 2009). Kua et al. (2010) reported that the $Z$. arugamensis required 16 to 17 days to complete their life cycle at $24^{\circ} \mathrm{C}-25^{\circ} \mathrm{C}$. Seven days were needed for the newly produced eggs to develop into larvae and another 9 to 10 days to reach adult stage. However, only $83.87 \%$ of juveniles reached adult stage. Moreover, Negoro (2017) stated that the life cycle of the $Z$. arugamensis was \pm 21 days.

\section{CONCLUSION}

It can be concluded that the marine leech isolated from hybrid grouper "cantik" is Zeylanicobdella arugamensis. The egg development until hatched using seawater with daily water exchange needed 10 days. The egg incubation with continuous running water had hatched earlier (eight days). The growth of larvae to reach adult phase took nine days. Overall, the $Z$. arugamensis isolated from hybrid grouper "cantik" required 17 to 22 days to complete their life cycle under $29^{\circ} \mathrm{C}-31^{\circ} \mathrm{C}$ at $34-35$ ppt of seawater.

\section{ACKNOWLEDGEMENTS}

The authors would like to thank Mrs. Sri Suratmi and Mr. Ketut M. Arya Sudewa, the technicians at pathology laboratory, Institute for Mariculture Research and Fisheries Extension, and Mr. Ahkmad Fauzy, a student at Polytechnics of Marine and Fisheries, Sidoarjo, Surabaya for their assistance during the study.

\section{REFERENCES}

Ahmed, R.B., Gammoudi, M., Khaled, I., Tekaya, S., Mansour, L., Alwasel, S., \& Harrath, A.H. (2015a). Annotations on marine and freshwater leeches (Annelida, Clitellata, Hirudinea) from North Africa. Tropical Zoology J., 28(2), 1-22. https://doi.org/ 10.1080/03946975.2015.1046737.

Ahmed, R.B., Romdhane, Y., \& Tekaya, S. (2015b). Checklist and distribution of marine and freshwater leeches (Annelida, Clitellata, Hirudinea) in Tunisia with identification key. Ecologica Montenegrina J., 2(1), 3-19.

Arslan, N., \& Oktener, A. (2012). A general review of parasitic Annelida (Hirudinea) recorded from dif- 
ferent habitats and hosts in Turkey. Turk. J. Zool., 36(1), 141-145.

Bulguroglu, S.Y., Korun, J., \& Gökoglu, M. (2015). New information on distribution of a marine leech, Pontobdella muricata (Linnaeus, 1758), from the Mediterranean coast of Turkey. The Journal of Biodiversity, 11(2), 1588. http://dx.doi.org/10.15560/ 11.2.1588.

Chandra, M. (1983). Zeylanicobdella arugamensis. Rec. Zool. Surv. India, 80, 268-273.

Chandra, M. (1991). A check-list of leeches of India. Surv. India, 80, 265-290.

Cruz-Lacierda, E.R.C., Toledo, J.D., Fermin, J.D.T., \& Burreson, E.M. (2000). Marine leech (Zeylanicobdella arugamensis) infestation in cultured orange-spotted grouper, Epinephelus coioides. Aquaculture, 185(3-4), 191-196.

Curran, S.S., Phillips, A.J., Overstreet, R.M., Benz, G.W., \& Henningsen, A.D. (2016). Austrobdella cairae sp., an oioxenous marine leech (clitellata: Piscicolidae) from the banded guitarfish, Zapteryx exasperate, in the Northeastern Pacific Ocean. Journal Parasitology, 10(2), 179-186.

Govedich, F.R., \& Bain, B.A. (2005). All about Leeches. Retrieved from http://www.invertebrate.ws.

Hall, T.A. (2011). BioEdit: An important software for molecular biology. GERF Bulletin of Biosciences, 2(1), 60-61.

Jakob, J., \& Palm, H.W. (2006). Parasites of commercially important fish species from the southern Java coast, Indonesia, including the distribution pattern of trypanorhynch cestodes. Verhandlungen der Gesellschaft für Ichthyologie, Band, 5, 165-191.

Kleinertz, S., \& Palm, H.W. (2013). Parasites of the grouper fish Epinephelus coioides (Serranidae) as potential environmental indicators in Indonesian coastal ecosystems. Journal of Helminthology, 89, 86-99.

Kleinertz, S., Damriyasa, I.M., Hagen, W., \& Theisen, S. (2014). An environmental assessment of the parasite fauna of the reef-associated grouper Epinephelus areolatus from Indonesian waters. Journal of Helminthology, 88, 50-63.

Koesharyani, I., Roza, D., Mahardika, K., Johnny, F., Zafran, \& Yuasa, K. (2001). Manual for fish disease diagnosis-II. Marine fish and crustacean diseases in Indonesia. Gondol Research Institute for Mariculture, Central Research Institute for Sea Exploration and Fisheries, Dep. of Marine Affair and Fisheries, and Japan International Cooperation Agency, p. 5-7.
Kua, B.C., Azmi, M.A., \& Hamid, N.K.A. (2010). Life cycle of the marine leech (Zeylanicobdella arugamensis) isolated from sea bass (Lates calcarifer) under laboratory conditions. Aquaculture, 302, 153-157.

Kua, B.C., Choong, F.C., \& Leaw, Y.Y. (2014). Effect of salinity and temperature on marine leech, Zeylanicobdella arugamensis (De Silva) under laboratory conditions. J. Fish Dis., 37(3), 201-207.

Metcalfe, L., Fox, M.E., \& Carey, J.H. (1984). Aquatic leeches (hirudinea) as bioindicators of organic chemical contaminations in freshwater ecosystems. Chemosphere, 13(I), 143-150.

Moser, W.E., Govedich, F.R., \& Klemm, D.J. (2009). Annelida, Hirudinida (leeches). Invertebrates, p. 116123.

Negoro, S.L.C. (2017). Prevalency, intentity and caracteristic of ectoparasite hirudinea on grouper fish (Epinephelus spp.) in floating net cage. Undergraduate Thesis. Faculty of Agriculture, Gadjah Mada University, Yogyakarta. 62 pp (Indonesian).

Neubert, K., Yulianto, I., Kleinertz, S., Theisen, S., Wiryawan, B., \& Palm, H.W. (2016). Parasite fauna of white-streaked grouper, Epinephelus ongus (Bloch, 1790) (Epinephelidae) from Karimunjawa, Indonesia. Parasitology, 0(e0), 1-11.

Palm, H.W. (2011). Fish parasites as biological indicators in a changing world: Can we monitor environmental impact and climate change? p. 223-250 in Mehlhorn, H. (Ed.). Progress in parasitology. Berlin, Springer-Verlag. Parasitology Research Monographs, 2, 223-250.

Ravi, R., \& Yahaya, Z.S. (2017). Zeylanicobdella arugamensis, the marine leech from cultured crimson snapper (Lutjanus erythropterus), Jerejak Island, Penang, Malaysia. Asian Pac. J. Trop. Biomed., 7(5), 473-477.

Sawyer, R.T., Taylor, A., \& Sahat, M.J.H. (1982). The leeches of Brunei (Annelida: Hirudinea), with a checklist and key to the known and expected freshwater, terrestrial and marine leeches of Borneo. Brunei mus., 5(2), 168-201.

Sket, B., \& Trontelj, P. (2008). Global diversity of leeches (Hirudinea) in freshwater. Hydrobiologia, 595, 129-137.

Tevsky, S.Y.U., \& Trontelj, P. (2004). Phylogenetic relationships of fish leeches (Hirudinea, Piscicolidae) based on mitochondrial DNA sequences and morphological data. Zoologica Scripta, 33, 375-385.

Yuniar, A.T., Palm, H.W., \& Walter, T. (2007). Crustacean fish parasites from Segara Anakan Lagoon, Java, Indonesia. Parasitology Research, 100, 1193-1204. 